\title{
Role of Information and Communication Technology in Applying Quality Control Procedures in Audit Offices in the Hashemite Kingdom of Jordan
}

\author{
Reem Aqab ${ }^{1}$ \\ ${ }^{1}$ Al-Balqa Applied University, Jordan \\ Correspondence: Reem Aqab, Al-Balqa Applied University, Jordan. \\ Received: May 16, 2019 \\ Accepted: June 11, 2019 \\ Online Published: June 18, 2019 \\ doi:10.5539/ibr.v12n7p57 \\ URL: https://doi.org/10.5539/ibr.v12n7p57
}

\begin{abstract}
The study aims to determine the impact of information technology on quality control elements and procedures, including vocational requirements, personal management procedures, client acceptance and continuance, audit performance, and following up and monitoring procedures used by auditing offices in Hashemite Kingdom of Jordan.

The researcher has used descriptive analytical approach for conducting relevant literature reviews. In addition, a questionnaire has been distributed to study sample (i.e audit offices) in order to identify to which extent information technology affects audit quality control.

The recent study has found that information technology affects highly quality control procedures and elements including vocational requirements, personal management procedures, client acceptance and continuance, plus audit performance in audit offices. In addition, it has concluded that information technology has a medium impact on following-up and monitoring procedures used by audit offices moreover, the study showed that using information technology has contributed to achieve quality control goals, desired.
\end{abstract}

Keywords: quality control, information technology, auditing, Jordan

\section{Introduction}

Auditing is an essential economic and social profession imposed by laws and legislations and guaranteed by various vocational, controlling and educational authorities in many countries of the world including Jordan. It, therefore, shall be applied according to international standards on auditing.

Audit quality concept is relatively recent and receives an academic and vocational attention. Audit profession has faced a lot of criticism because of lawsuits which were filed against the auditors and a failure of some international audit firms. As a result, various quality control standards and instructions governing audit process were developed by international organizations. Thus, this study has sought to identify the impact of information technology on quality control procedures applied by audit offices in the light of information technology used recently by various business and audit organizations.

Information technology is an effective and important tool that affects directly the methods organizing audit office works and quality control elements, thereby improving the performance of audit offices. These new perspectives of using information technology in audit and accounting processes have not been mentioned in accounting and auditing literature.

\section{Important of the Study}

Information Technology has been used in various life fields. Through using information technology, organizations' goals and purposes have been achieved and process costs have been decreased. This study, therefore, is importance since it identifies to which extent the auditor can use information technology in order to organize audit office works and apply quality control elements. In addition, it identifies to which extent using information technology improves audit profession.

\section{Purposes of the Study}

The study is to identify quality control importance and concept used by audit offices according to international 
standards. It also aims at identifying the impact of information technology on quality control measurements. In addition, it clarifies the possibility of using information technology in order to apply quality control elements. Moreover, the recent study aims at surveying Jordanian auditors' opinions related to the use of information technology in order to demonstrate the impact of information technology on quality control procedures and elements, including personal management, client acceptance and continuance plus audit performance, following up and monitoring procedures in audit offices.

\section{Problem of the Study}

The study has been conducted due to rapid technological developments and massive use of information technology in various economic sectors. In addition, It helps identify the possibility of getting benefit of information technology in order to apply quality control procedure in audit offices. The study, therefore, seeks to answer the following research question:

What is the impact of using information technology on quality control elements and procedures including personal management, client acceptance and continuance, audit performance, plus following up and monitoring procedures applied by audit offices in the Hashemite Kingdom of Jordan?

\section{Hypotheses of the Study}

This study tests the following main hypothesis :

There is no statistically significant relationship between the use of information technology and quality control elements and procedures including personal management, client acceptance and continuance, audit performance plus following up and monitoring procedures applied by audit offices in the Hashemite Kingdom of Jordan.

The study also tests the following sub-hypotheses related to quality control elements :

- There is no statistically significant relationship between the use of information technology and the compliance with vocational requirements applied by audit offices in the Hashemite Kingdom of Jordan .

- There is no statistically significant relationship between the use of information technology and personal management applied by audit offices in the Hashemite Kingdom of Jordan .

- There is no statistically significant relationship between the use of information technology and client acceptance and continuance applied in audit offices in the Hashemite Kingdom of Jordan .

- There is no statistically significant relationship between the use of information technology and acceptance and the accuracy of audit performance in audit offices in the Hashemite Kingdom of Jordan .

- There is no statistically significant relationship between the use of information technology and the consultations in audit offices in the Hashemite Kingdom of Jordan .

- There is no statistically significant relationship between the use of information technology and following up and monitoring procedures applied by audit offices in the Hashemite Kingdom of Jordan .

\section{Study Model}

The following figure illustrates the relationship between study variables:

Independent Variable

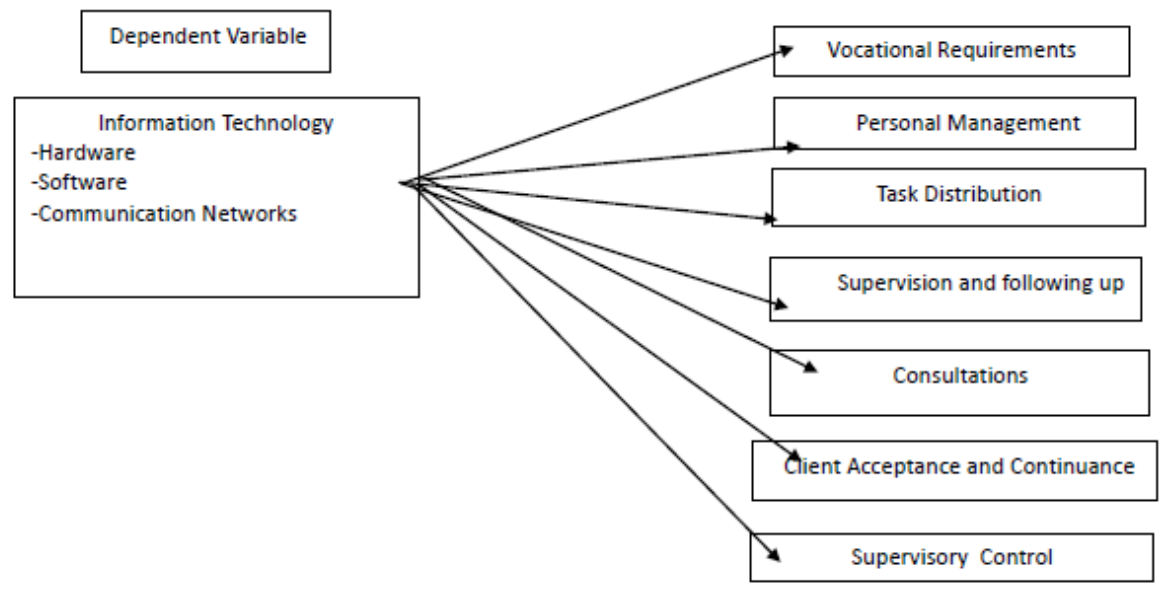




\section{Theoretical Frame and Previous Studies}

Various studies touched upon information technology and audit: some of these studies have been listed below:

-Helms. 2001 study entitled "Traditional and Modern Methods In E-Assurance" was to compare between traditional and modern methods used in E-assurance field linked to the development of company environment resulting from e-commerce and information technology. It also aimed at identifying the best methods of collecting sufficient evidences suitable for Introduction to the continuous audit which has gathered between the methods of collecting traditional and electronic evidences in the light of continuous audit processes. The researcher used theoretical approach. He reviewed accounting literatures and studied contemporary developments. The study identified the most significant methods of collecting computerized audit evidences, plus predefined audit programs, in addition to office management programs. It also iluustrated security and monitoring programs, comparison programs, flow chart programs and phonographic documents .

-Liang 2001 study entitled "E-Auditing of E-Data Using Modern Information Technology aimed at discussing the requirements of applying computer assisted audit techniques (CAATS) with the support of the modern information technologies such as medium routing system, internet security technology and smart agents. In addition, it was to suggest introduction to new audit called E-auditing; auditor should perform electronically audit tasks via internet; all accounting system processes should be operated and saved in the company, the place of e-audit processes. The study was conducted in audit offices in order to examine loan and interest accounts and debtors at commercial banks in Taiwan. According to this study, e-audit model could be applied; it based on typical e-audit programs and modern information technologies mentioned previously. Accordingly, auditor could enter databases of credit section in the bank; he/ she could apply typical audit trail programs, prepare a report on exceptions and send the approvals via e-mail .

-Khadash and Siyam, 2003 study, entitled 'The Extent to Which Auditors Accept the Use of Information Technology in Audit - A Field Study of the Largest audit Offices In Jordan" aimed to highlight the importance of using information technology in audit processes. It also was to test the reality of using information technology; in addition, it aimed at illustrating the obstacles encountered by information technology. The study found that auditors in Jordan were convinced of the importance of using information technology in audit and they realized that using information technology has raised the precision of work, improved the efficiency and decreased the cost. However, the actual use of information technology did not meet the required level because of various obstacles such as manual accounting application in some companies subject to audit, a lack of experience and skills of some auditors, and the absence of binding legislations that has organized the use of information technology in accounting and audit .

-Al-Dnebat, 2002 study, entitled 'The Extent and Effectiveness of The Use of Information Technology in Audit Process In Jordan' aimed at identifying the fields of using information technology in audit and its impact on audit's effectiveness. The study concluded that auditors in Jordan used information technology in the field of planning, documenting and recording audit processes. The average of using information technology in these fields has been low although it increased the efficiency of audit process, and decreased the time spent in calculation writing; it also lowered the number of employees working in audit offices plus audit costs. The study recommended that Jordanian Association of Auditors should hold training courses which have aimed at introducing the use of information technology in line with international trend towards computerization of education and services, among other. The researcher recommended that using information technology in audit has been a national demand which could improve audit service level and increase the competitiveness of profession members locally and globally .

-]Al-Juhar, Al-Aqdeh and Abu Sardineh, 2010 study, entitled 'The Impact of Using Technology On Work Quality of External Auditor: A field Study in Some Jordanian Audit Offices', aimed at highlighting the dimensions of the impact of information technology on audit and the risks it may face. It also identified to which extent these risks affect quality standards of auditor work. A questionnaire was distributed to audit office sample study working in Jordan in order to collect the data. The study found that the risk could be faced by audit office has been the exposure due to a lack of controlling procedures associated with the use of technology. It also showed that vocational quality standards highly affected by the risks of technology have been the competence and merit standards.

It can be said that this study is distinguished because it has touched upon the impact of technology on quality control procedures followed by audit offices. The recent study has also illustrated the possibility of using information technology in applying quality control elements. Other studies have identified to which extent information technology could be used for performing audit processes. They also outlined the possibility of 
converting to electronic audit .

\section{Theoretical Frame}

\section{Information Technology and Quality Control Procedures}

This section discusses various topics in information technology; it also examined quality control concept. In addition, it illustrates the relation between the importance of using information technology and quality control procedures and elements applied in audit processes.

\section{Information Technology Concept}

It is worth mentioning that no specific scientific or practical definition of information technology is available at global, Arabic or local levels due to multiple environments and works created by information technology. The following is a set of various definitions of information technology environment :

It is the latest concept of technological development which overcomes time and distance barriers of transportation and communication between countries. Electronic means of voice communications and data transmission including e-mail, fax, internet and global speed telephone network are developed .

It is a performance model which consists of a compound dynamic combination of advanced technical equipment such as computers, internet, and laborers. This model aims at operating the data and conveying them as up-to-date as quickly as possible to the users all over the world (Abdelfattah, Sawsan, 2000).

It is a result of the convergence of the sciences of physics, logical, engineering and electronic mathematics. Thus, revolution of information technology i.e the mode of integration of triad (computers- software - networks) occurred. (Ali, Nabil, 2001).

The researcher believes that information technology includes the use of specialized software in computers for processing the data and conveying the information among business organizations via communications networks .

\section{Quality Control concept in Audit Service Industry}

Quality control concept is related to industrial sector; it refers to regular means and methods used for inspecting and testing the product after manufacturing in order to ensure the availability of predetermined specifications. In industrial sector, specific standards are used for creating an objective measurement tool which covers all sector including service sector. However, Vocational organizations develop and formulate specific quality standards of audit services due to the importance of audit field .

Accordingly, there is no agreement on a practical and unified definition of audit quality (Paul A. Copley and Mary S Doucet, P.8) because audit quality is characterized by the following features: (De Angelo, LE, 1981.p.113.(

- It is intangible; audit activities are services which cannot be valued and measured in advance.

- It is intangible; there is a massive variation of performing and providing services from time to time. For example, work team performance varies according to time and work pressure. In addition, a variation of opinions and needs of service beneficiaries is available. Finding a unified measurement of audit quality, therefore, becomes difficult.

- Evaluation of audit quality and service is more difficult than product quality evaluation due to a lack of experience .

- Audit quality can be identified when a comparison between beneficiaries' expectations and actual performance of provided service is conducted.

- Service quality is not only assessed by the results (the output) but also by the method and processes of service performance ( the input).

Based on the above mentioned, the researcher believes that audit quality can be defined as the following:

It is a tool of ensuring that vocational performance complies with vocational standards; it includes various procedures and polices followed by audit offices in order to apply recognized audit standards and control work quality of offices as a whole.

\section{Importance of Information Technology in Applying Quality Control Procedures}

Importance and credibility of audit profession are closely related to service quality; daily work pressure, client requirements, and other factors make it easy for audit offices to throw caution to the wind, thereby providing a low level of work quality. Information technology has various advantages since it has been used in various 
sectors and in the application of control quality in audit offices. The importance of information technology in applying audit quality can be summed by the following points :

- The use of information technology in applying quality control procedures contributes to improve the level of trust in audit profession in information technology environment .

- Documenting work papers is improved because certain documentation policies are followed and information technology is applied in office work documentation .

- Audit Assurances illustrating that office services are in line with vocational requirements are given .

- A view of community toward audit profession has improved .

- Customer relationships are improved since more accuracy and attention during work are expressed and information technology is used in order to contact the clients.

- Fertile ground is provided for attracting new clients and increasing market share in the light of competition conditions and advertising restrictions plus information technology development .

- Instructions and procedures of polices adopted by audit company are provided; these polices provide a reasonable level of audit assurance; and they forces audit offices to follow information technology environment standards. As a result, audit offices can avoid vocational and legal penalties .

- Operational costs of audit processes are decreased; efficiency and effectiveness of task performance are improved; time and effort exerted in re-working are reduced .

\section{Audit Quality Control Elements in Audit and Information Technology Offices}

International audit and assurance standards emphasize that audit offices shall have control system providing a reasonable level of audit assurance. Thus, such system clarifies that vocational work team of audit office follows recognized audit standards in general. Audit quality control elements are discussed below (International Arab Society Of Certified Accountants, 2003)

\section{Vocational Requirements}

According to vocational requirements, all partners and employees working in audit office shall commit to the principles of independence, objectivity, integrity, confidentiality and vocational conduct. Conducting a periodic survey pertaining to office clients is main step of procedures because it ensures that office is reasonably committed to the control elements. Then, this survey shall distributed to all office members and companies; they shall certify that they have no interests with the clients such as owing shares, working as a supplier, or board membership) and they have no relatives occupying sensitive jobs at client's premises. Information technology contributes to apply effectively quality control procedures through computerizing periodic survey lists and using modern software contributing to select audit team .

\section{Personal Management}

Based on personal management procedures, audit office management shall develop a set of policies and procedures because they ensure reasonably that all employees in audit office are qualified to perform vocational work with a high vocational competence. For example, vocational employees who obtain a minimum required average during undergraduate level shall be recruited; all employees shall participate in continuous vocational education and training programs which contribute to increase knowledge and carry out the required responsibilities to the fullest extent. All persons selected and promoted to greater responsibility positions in audit office shall have adequate and appropriate qualification such as merit, creativity, intelligence and seniority in order to meet their responsibilities. Information technology contributes to manage employee relations through using specialized programs and preparing continuous vocational training programs .

\section{Task Distribution}

Based on task distribution procedures, policies and procedures ensuring that vocational employees with a high level of technical training and required scientific and practical experience shall be available because they shall be able to perform audit process after audit requirements are taken into account. Work team is a significant element since it performs audit work. In addition, a balance between work team and individual skills, plus size and complexity of audit, person availability, and special experiences plus work time and training chance in work site shall be achieved. Using information technology, particularly data basis which includes knowledge skills, enables audit management to select adequate skillful auditor. Selection process can be computerized by using advanced electrical programs . 


\section{Supervision}

According to supervision procedures, policies and procedures which aim at supervising and reviewing the works at all organizational levels shall be available because they ensure reasonably that the work performed is consistent with vocational standards plus quality control standards. Electronic means can be used for supervising audit processes and ensuring that audit process is performed in a timely manner.

\section{Consultation}

Based on consultation procedures, all persons shall be encouraged to ask helping from vocational skilful employees. The office shall perform a set of procedures. For example, the office shall identify the specialists and shall determine their responsibilities and powers in investment fields in order to avoid errors or problems with clients or legal accountability. Computerizing audit office works includes availability of files which contain names and addresses of persons. Thus, auditor can contact them easily .

\section{Client Acceptance and Continuance}

Based on client acceptance and continuance, current and prospective clients shall evaluated periodically because audit has to determine if it shall associate with potential clients or it shall continue with current clients. But, independence of audit office, ability to provide clients with suitable services and client management reputation shall be taken into account. Office activities shall be limited to tasks the office can effectively and adequately perform within information technology environment. Modern software such as decision support systems contributes to make a decision of accepting or refusing the clients; modern software provides a possibility of assessing the risks of essential distortions in financial statements .

\section{Supervisory Control}

According to supervisory control procedures, a set of policies and procedures, ensuring that audit control elements mentioned previously are effectively applied by all office members, shall be available. To meet these procedures, peer review program, a tool of inspecting audit office performance, shall be applied; office procedures and policies are reviewed. Inspection team examines and assesses quality control system of office performance plus the policies and procedures. Information technology provides easily all information on quality control and contributes to exchange the policies via communication networks .

\section{Methodology of the Study}

Data Collection Methods

The researcher has used two methods in order to collect data :

- Inductive Method:

It depends on previous analysis and studies plus accounting literatures and vocational publications. It aims at identifying the impact of information technology on quality control procedures followed by audit offices .

- Practical Method:

The researcher has designed a questionnaire based on the theoretical frame; the questionnaire has been distributed to population study.

\section{Study Population and Sample}

Study population is audit offices in the Hashemite Kingdom of Jordan; study sample consists of (33) thirty three audit offices in Amman; 20 offices have been selected in order to provide a clear picture of quality control procedures in audit offices, plus office size, employee number and a variety of services audit which offices provide .

\section{Validity and Reliability of Study Tool}

\section{Validity of Study Tool:}

The questionnaire has been arbitrated by a group of academic professors specialized in the fields of accounting, audit, statistics in order to verify its validity; the paragraphs the questionnaire contains measure the ideas for which it has been designed. Arbitrators' observations have been taken into account. Some paragraphs of questionnaire, therefore, have been reformulated in a manner that achieves a balance and consistency of the paragraphs of the questionnaire. 


\section{Reliability of Study Tool}

To test the validity of questionnaire results and the extent of availability of internal reliability among questionnaire's questions, Cronbach's alpha reliability coefficient has been used. Statistically accepted value of Cronbach's alpha has been $60 \%$ or more. Table 1 has identified that Cronbach's alpha value of respondents' answers to all questions of each field has been higher than a minimum accepted level of Cronach's alpha. Thus, a high degree of internal reliability is available among answers. Study tool, therefore, has a high value of reliability and its answers can be adopted in order to achieve study purposes. Table 1 outlines the results of Cronbach's alpha test.

Table 1. Reliability Coefficients extracted by Cronbach's Alpha of Study Fields

\begin{tabular}{|c|c|c|c|}
\hline Field & & Results & \\
\hline & Number of Questions & Cronbach's Alpha & Results \\
\hline $\begin{array}{l}\text { Information technology and its } \\
\text { impact on vocational } \\
\text { requirements }\end{array}$ & 4 & 87 & Accepted \\
\hline $\begin{array}{l}\text { Information technology and } \\
\text { personal management in audit } \\
\text { offices }\end{array}$ & 16 & 72 & Accepted \\
\hline $\begin{array}{l}\text { Information technology and } \\
\text { client acceptance } \\
\text { continuance }\end{array}$ & 5 & 97 & Accepted \\
\hline $\begin{array}{l}\text { Information technology and its } \\
\text { impact on audit performance }\end{array}$ & 7 & 86 & Accepted \\
\hline $\begin{array}{l}\text { Information technology and } \\
\text { consultations in audit offices }\end{array}$ & 9 & 86 & Accepted \\
\hline $\begin{array}{l}\text { Information technology and } \\
\text { follow-up procedures in audit } \\
\text { offices }\end{array}$ & 4 & 82 & Accepted \\
\hline
\end{tabular}

\section{Descriptive Analysis of Sample Study's Answers}

In this section, respondents' answers have been analyzed by using statistical package for social sciences (SPSS); each set of questions has been named as a field by the researcher according to the criteria of descriptive analysis of questionnaire in order to reflect study hypotheses. For the purposes of characterization of data and respondents' answers, each paragraph has been divided according to fifth Likert scale.

\begin{tabular}{llllll}
\hline Category & Very high impact & High impact & Moderate impact & Very low impact & No impact at all \\
\hline Coding & 5 & 4 & 3 & 2 & 1 \\
\hline
\end{tabular}

According to table mentioned above, moderate arithmetic mean has been 3; it has been extracted from total number of values. An approved ratio of impact is 3 divided by 5 (i.e $60 \%$ ). Accordingly, values of arithmetic means which the study has reached will be processed in order to explain the data as follows :

\begin{tabular}{ccccc}
\hline 1 & 2 & 3 & 4 & High impact \\
\hline No impact at all & Very low impact & moderate impact & Very high impact \\
\hline $1.79-1$ & $2.59-1.80$ & $3.39-2.60$ & $4.19-3.40$ & $5-4.20$ \\
\hline $\begin{array}{c}\text { Information technology } \\
\text { has no impact on } \\
\text { quality control at all }\end{array}$ & $\begin{array}{c}\text { Information } \\
\text { technology has a } \\
\text { very low impact on } \\
\text { quality control }\end{array}$ & $\begin{array}{c}\text { Information } \\
\text { technology has a } \\
\text { moderate impact on } \\
\text { quality control }\end{array}$ & $\begin{array}{c}\text { Information technology has } \\
\text { a high impact on quality } \\
\text { control }\end{array}$ & $\begin{array}{c}\text { Information } \\
\text { techology has a very } \\
\text { high impact on } \\
\text { quality control }\end{array}$ \\
\hline
\end{tabular}

Based on the table above, the results of statistical analysis of the data are explained .

\section{Characteristics of Study Sample}

In order to identify the characteristics of study sample, questionnaire list has included a set of questions representing a general information of study sample. Table 2 outlines demographic characteristics of the respondents .

Table 2 shows the demographic characteristics of sample study as the following:

- Number of employees in the office: It is noted that the number of offices which hire more than 12 employees is 12 (i.e 60\%). Thus, respondents' answers contribute to achieve the purposes of the study. So, the more the number of employees increases the more the size of audit office increases. Accordingly, applying quality control procedures and policies becomes necessary .

- Number of auditors holding vocational certifications: Table 2 shows that audit offices hire academic vocational and skilful employees; such matter is one of quality control requirements . 
- Existence of Department of Quality Control in Audit Office: It is noted that $15 \%$ of audit offices have no department of quality control and $85 \%$ of audit offices have department of quality control. Accordingly, respondents' answers contribute to achieve the purposes of the study .

Table 2. Frequencies and Percentages according to Study Variables

\begin{tabular}{cccc}
\hline & Category & Frequency & Percentage \\
\hline Number of Employees & Less than 3 persons & 5 \\
& From 3 to less than 12 & 7 & 35 \\
& More than 12 persons & 12 & 60 \\
Total & & 20 & 100 \\
certifications & Jordanian audit license & 40 & 70 \\
& & & 25 \\
Existence of Department of Quality & Certified Public Auditor (CPA ( & 3 & 5 \\
Control in Audit Office & British Certified Public Auditor & 57 & 100 \\
& Total & 3 & 15 \\
& & 17 & 85 \\
\hline
\end{tabular}

\section{Data Analysis and Hypothesis Testing}

In this section, respondents' answers pertaining to the impact of information technology on quality control in audit offices are descriptively analyzed; the following is the descriptive analysis of each field :

\section{First Hypothesis Testing}

In order to validate this hypothesis, arithmetic means and standard deviations have been extracted; the relation between the impact of information technology and vocational requirements of quality control in audit offices has been measured. Table 3 outlines arithmetic means and standard deviations of vocational requirements of quality control in audit offices.

Table 3. Arithmetic Mean and Standard Deviation of Vocational Requirements of Quality Control in Audit Offices

\begin{tabular}{|c|c|c|c|}
\hline \begin{tabular}{|c|} 
Sentences \\
\end{tabular} & Arithmetic mean & Standard Deviation & Answer Orientation \\
\hline $\begin{array}{l}\text { Office employees use information } \\
\text { technology and address the issues related } \\
\text { to the vocational requirements by using } \\
\text { information technology means }\end{array}$ & 4 & 0.49 & high impact \\
\hline $\begin{array}{l}\text { Information technology helps audit offices } \\
\text { document and save the consultations }\end{array}$ & 4.14 & 0.49 & high impact \\
\hline $\begin{array}{l}\text { Information technology helps audit offices } \\
\text { save an update list of client names }\end{array}$ & 4.71 & 0.49 & Very high impact \\
\hline $\begin{array}{l}\text { Information technology helps audit offices } \\
\text { issue certain forms periodically in order to } \\
\text { be filled by the employees; by filing these } \\
\text { forms, the employees recognize that they } \\
\text { know office policies and procedures of } \\
\text { independency and do not perform finical or } \\
\text { commercial transactions and relations } \\
\text { forbidden by office policies of } \\
\text { independency }\end{array}$ & 4.71 & 0.49 & Very high impact \\
\hline Total & 4.39 & 0.45 & Very high impact \\
\hline
\end{tabular}

Answers of the questions of vocational requirements have showed that information technology has a very positive and high impact; the answers of study sample have indicated that they contribute to maintain vocational requirements; total calculated arithmetic mean is 4.39 ; it is higher than the default mean which is 3 . The orientation of the answers has indicated that information technology has a very high impact .

In addition, arithmetic mean of the paragraphs which form first hypothesis has been compared with standard mark 3 - hypothesis acceptance standard- by using t-test as stated in table 4 .

Table 4. Arithmetic Means and Standard Deviations and T-test of Paragraphs which form first hypothesis

\begin{tabular}{ccccccc}
\hline & Number & $\begin{array}{c}\text { Arithmetic } \\
\text { Mean }\end{array}$ & $\begin{array}{c}\text { Standard } \\
\text { Deviation }\end{array}$ & T-Value & $\begin{array}{c}\text { Freedom } \\
\text { Degree }\end{array}$ & $\begin{array}{c}\text { Statistical } \\
\text { Significance }\end{array}$ \\
\hline $\begin{array}{c}\text { Information technology and its } \\
\text { impact on vocational requirements }\end{array}$ & 20 & 4.39 & 45. & 10.967 & 21 & 000. \\
\hline
\end{tabular}


Table 4 has indicated that there are statistical differences at $(=0.05)$ between arithmetic mean and standard deviation 3; T-value has been 10.967; statistical significance has been 0.000 . Thus, the hypothesis, stating that there is no statistically significant relationship between the use of information technology and the compliance with vocational requirements applied by audit offices in the Hashemite Kingdom of Jordan, has been rejected; alternative hypothesis, stating that there is statistically significant relationship between the use of information technology and the compliance with vocational requirements applied by audit offices in the Hashemite Kingdom of Jordan, has been accepted .

\section{Second Hypothesis Testing}

In order to validate this hypothesis, arithmetic means and standard deviations have been extracted; the relation between the impact of information technology and personal management in audit office has been measured. Table 3 outlines arithmetic means and standard deviations of vocational requirements of quality control in audit offices.

Table 5. Arithmetic means and Standard Deviations of the impact of information technology on Personal Management in Audit Offices

\begin{tabular}{|c|c|c|c|}
\hline Sentences & $\begin{array}{c}\text { Arithmetic } \\
\text { mean }\end{array}$ & $\begin{array}{c}\text { Standard } \\
\text { Deviation }\end{array}$ & $\begin{array}{c}\text { Answer } \\
\text { Orientation }\end{array}$ \\
\hline \multicolumn{4}{|l|}{ Personal management } \\
\hline \multicolumn{4}{|l|}{ • Recruitment: } \\
\hline $\begin{array}{l}\text { The office uses information technology in order to express numerically the } \\
\text { needs of skillful employees of information technology at all levels. }\end{array}$ & 3.71 & 49 & High impact \\
\hline $\begin{array}{l}\text { The office follows certain policies and procedures; they are implemented by } \\
\text { the employees who have experience of information technology and have a } \\
\text { responsibility to make decisions of recruitment }\end{array}$ & 4.41 & 0.90 & High impact \\
\hline $\begin{array}{l}\text { Information technology is a standard of evaluating the candidates for the job } \\
\text { - Vocational Development }\end{array}$ & 4.71 & 0.49 & Very high impact \\
\hline $\begin{array}{l}\text { Information technology is used in the office in order to develop vocational } \\
\text { development programs for the employees in the offices }\end{array}$ & 4.71 & 0.49 & Very high impact \\
\hline $\begin{array}{l}\text { Persons who are skillful in information technology review these programs in } \\
\text { order to ensure their consistency and achievement of office goals }\end{array}$ & 4.71 & 0.49 & Very high impact \\
\hline $\begin{array}{l}\text { The office identifies vocational requirements by using information } \\
\text { technology at all job levels in the office }\end{array}$ & 4.14 & 0.9 & High impact \\
\hline $\begin{array}{l}\text { The office updates electronic data of vocational qualification procedures in } \\
\text { order to monitor the continuance of vocational qualification efforts }\end{array}$ & 3.71 & 0.49 & High impact \\
\hline $\begin{array}{l}\text { The office has an electronic record including the data of all office activities } \\
\text { and employees }\end{array}$ & 4.43 & 0.98 & Very high impact \\
\hline $\begin{array}{l}\text { The office provides local and international books and publications on } \\
\text { accounting, audit, information technology development and legal and } \\
\text { legislative requirements, among other }\end{array}$ & 4.29 & 0.49 & Very high impact \\
\hline $\begin{array}{l}\text { The office develops training program for the employees by using information } \\
\text { technology }\end{array}$ & 4.57 & 0.53 & Very high impact \\
\hline \multicolumn{4}{|l|}{ • Promotion } \\
\hline $\begin{array}{l}\text { There is an electrical job description of works performed by the employee } \\
\text { and the responsibilities undertaken by all employees at all job levels }\end{array}$ & 4.71 & 0.49 & Very high impact \\
\hline $\begin{array}{l}\text { Information technology is used for collecting and evaluating the information } \\
\text { on employee achievements according to job levels }\end{array}$ & 4.71 & 0.49 & Very high impact \\
\hline $\begin{array}{l}\text { A part of job evaluation of employees is electronically and periodically } \\
\text { conducted within a specific period of time. }\end{array}$ & 5 & 0 & Very high impact \\
\hline $\begin{array}{l}\text { Certain standards are taken into account when employee performance and } \\
\text { capability are evaluated within information technology environment in term } \\
\text { of technical knowledge of information technology }\end{array}$ & 5 & 0 & Very high impact \\
\hline $\begin{array}{l}\text { Certain standards including experience of information technology, capability, } \\
\text { and achievements of information technology environment are taken into } \\
\text { account when employees are promoted to higher job levels }\end{array}$ & 5 & 0 & Very high impact \\
\hline $\begin{array}{l}\text { Evaluation results are electronically documented in special file of the } \\
\text { employee }\end{array}$ & 5 & 0 & Very high impact \\
\hline $\begin{array}{l}\text { Assessment and guidance system for the employees is periodically reviewed } \\
\text { in order to ensure its effectivity and achievement of the desired goals within } \\
\text { information technology environment }\end{array}$ & 5 & 0 & Very high impact \\
\hline Total & 4.43 & 0.18 & Very high impact \\
\hline
\end{tabular}

Table 5 has showed that arithmetic mean is 4.43 ; it is higher than hypothetical mean which is 3 . Answer orientation of study sample has indicated that information technology affects very highly personal management in audit offices; it affects the identification of the number of the employees which the office needs. In addition, 
audit office management seeks to develop employees' skills through using information technology and computer because the importance of using information technology has increased and IT audit concept has appeared. Availability of specialized work team of IT audit, therefore, has become a necessity in the light of information technology .

In addition, arithmetic mean of the paragraphs which form second hypothesis has been compared with standard mark 3 - hypothesis acceptance standard- by using t-test as stated in table 6 .

Table 6. Arithmetic Means and Standard Deviations and T-test of Paragraphs which form second hypothesis

\begin{tabular}{lccccccc}
\hline & Number & $\begin{array}{c}\text { Arithmetic } \\
\text { Mean }\end{array}$ & $\begin{array}{c}\text { Standard } \\
\text { Deviation }\end{array}$ & $\begin{array}{c}\text { T-Value } \\
\text { Freedom } \\
\text { Degree }\end{array}$ & $\begin{array}{c}\text { Statistical } \\
\text { Significance }\end{array}$ \\
\hline $\begin{array}{l}\text { Information technology } \\
\text { personal management in } \\
\text { offices }\end{array}$ & 20 & 4.43 & 18. & 10.835 & 21 & 000. \\
\end{tabular}
offices

Table 6 has indicated that there are statistical differences at $(=0.05)$ between arithmetic means and standard deviation 3; T-value has been 10.835; statistical significance has been 0.000 . Accordingly, this hypothesis is rejected; the alternative hypothesis, stating that there is statistically significant relationship between the use of information technology and personal management applied by audit offices in the Hashemite Kingdom of Jordan, is accepted.

\section{Third Hypothesis Testing}

In order to validate this hypothesis, arithmetic means and standard deviations have been extracted; the relation between the impact of information technology and client acceptance and continuance in audit office has been measured. Table 7 outlines arithmetic means and standard deviations of client acceptance and continuance

Table 7. Arithmetic means and Standard Deviations of the Impact of Information Technology on Client Acceptance and Continuance

\begin{tabular}{|c|c|c|c|}
\hline Sentences & $\begin{array}{c}\text { Arithmetic } \\
\text { mean }\end{array}$ & $\begin{array}{l}\text { Standard } \\
\text { Deviation }\end{array}$ & $\begin{array}{c}\text { Answer } \\
\text { Orientation } \\
\end{array}$ \\
\hline \multicolumn{4}{|l|}{$\begin{array}{ll} & \text { Client Acceptance and Continuance } \\
\end{array}$} \\
\hline $\begin{array}{l}\text { Information technology helps audit offices assess the clients before } \\
\text { accepting the task }\end{array}$ & 4.14 & 1.25 & Very high impact \\
\hline $\begin{array}{l}\text { Information technology helps audit offices assess the clients by } \\
\text { electronically reviewing the financial statements and performing the } \\
\text { required analysis }\end{array}$ & 4.43 & 0.49 & Very high impact \\
\hline $\begin{array}{l}\text { Data bank containing the necessary information of the clients shall be } \\
\text { constructed }\end{array}$ & 4.43 & 0.49 & Very high impact \\
\hline Risks-related audit process shall be identified & 4.43 & 0.49 & Very high impact \\
\hline $\begin{array}{l}\text { Information technology helps audit offices review and assess the current } \\
\text { client; and they become able to identify client continuance when the } \\
\text { determined time periods end. }\end{array}$ & 4.43 & 0.82 & Very high impact \\
\hline Total & 4.43 & 0.16 & Very high impact \\
\hline
\end{tabular}

Table 7 has showed that total calculated arithmetic mean is 4.43; it is higher than the hypothetical mean which is 3. The orientation of the answers has indicated that information technology has a very high impact on client acceptance and continuance in audit offices; auditor shall study and understand client activity within information technology environment and used documents because he/she audits these documents in terms of id information technology risks pertaining to client acceptance and continuance. Accordingly, the hypothesis stating, that there is no statistically significant relationship between the use of information technology and client acceptance and continuance applied in audit offices in the Hashemite Kingdom of Jordan, is refused .

In addition, arithmetic mean of the paragraphs which form third hypothesis has been compared with standard mark 3- hypothesis acceptance standard- by using t-test as stated in table 8 .

Table 8. Arithmetic Means and Standard Deviations and T-test of Paragraphs which form third hypothesis

\begin{tabular}{ccccccc}
\hline & Number & $\begin{array}{c}\text { Arithmetic } \\
\text { Mean }\end{array}$ & $\begin{array}{c}\text { Standard } \\
\text { Deviation }\end{array}$ & T-Value & $\begin{array}{c}\text { Freedom } \\
\text { Degree }\end{array}$ & $\begin{array}{c}\text { Statistical } \\
\text { Significance }\end{array}$ \\
\hline $\begin{array}{c}\text { Information technology } \\
\text { and client acceptance } \\
\text { and continuance }\end{array}$ & 20 & 4.43 & 16. & 9.485 & 21 & 000. \\
\hline
\end{tabular}

Table 8 indicated that there are statistical differences at $(=0.05)$ between arithmetic mean and standard deviation 3; T-value has been 9.485; statistical significance has been 0.000. Accordingly, this hypothesis, stating that there is no statistically significant relationship between the use of information technology and client acceptance and continuance applied in audit offices in the Hashemite Kingdom of Jordan, is rejected and the 
alternative hypothesis, stating that there is statistically significant relationship between the use of information technology and client acceptance and continuance applied in audit offices in the Hashemite Kingdom of Jordan, is accepted .

\section{Fourth Hypothesis Testing}

In order to validate this hypothesis, arithmetic means and standard deviations have been extracted; the relation between the impact of information technology and audit performance in audit office has been measured. Table 9 outlines arithmetic means and standard deviations of audit performance .

Table 9. Arithmetic means and Standard Deviations of the Impact of Information Technology on Audit Performance

\begin{tabular}{|c|c|c|c|}
\hline Sentences & $\begin{array}{l}\text { Arithmetic } \\
\text { mean }\end{array}$ & $\begin{array}{c}\text { Standard } \\
\text { Deviation }\end{array}$ & $\begin{array}{c}\text { Answer } \\
\text { Orientation }\end{array}$ \\
\hline • $\quad$ Distribution of the tasks to the employees & & & \\
\hline Information technology helps audit offices plan the needs of employees & 4.43 & 0.53 & Very high impact \\
\hline $\begin{array}{l}\text { Information technology helps the office plan each individual audit task } \\
\text { including employee requirements and audit agenda }\end{array}$ & 4 & 0.0 & High impact \\
\hline $\begin{array}{l}\text { Information technology helps the office distribute the works to the } \\
\text { employees }\end{array}$ & 4 & 0.0 & High impact \\
\hline Authorization & & & \\
\hline Information technology contributes to assign appropriately audit task & 3.71 & 0.49 & High impact \\
\hline Information technology contributes to organize work documents and papers & 4.29 & 0. & Very high impact \\
\hline $\begin{array}{l}\text { Information technology helps audit office update previous information on } \\
\text { audit task according to new circumstances, estimate the time required for } \\
\text { performing the task and identify the needs of employees }\end{array}$ & 3.71 & 0.49 & High impact \\
\hline $\begin{array}{l}\text { Audit office provides special instructions and the content of work papers in } \\
\text { the light of using information technology }\end{array}$ & 4.29 & 0.49 & Very high impact \\
\hline 的 & 4.43 & 0.49 & Very high impact \\
\hline
\end{tabular}

Table 9 has showed that total calculated arithmetic mean is 4.43; it is higher than the hypothetical mean which is 3. The orientation of answers has indicated that information technology has a very high impact on audit performance; it is noticed that information technology helps audit office perform audit process in terms of planning and distribution of responsibilities. Accordingly, the hypothesis, stating that there is no statistically significant relationship between the use of information technology and acceptance and the accuracy of audit performance in audit offices in the Hashemite Kingdom of Jordan, is refused .

In addition, arithmetic mean of the paragraphs which form fourth hypothesis has been compared with standard mark 3- hypothesis acceptance standard- by using t-test as stated in table 10 .

Table 10. Arithmetic Means and Standard Deviations and T-test of Paragraphs which form fourth hypothesis

\begin{tabular}{ccccccc}
\hline & Number & $\begin{array}{c}\text { Arithmetic } \\
\text { Mean }\end{array}$ & $\begin{array}{c}\text { Standard } \\
\text { Deviation }\end{array}$ & $\begin{array}{c}\text { T-Value } \\
\text { Freedom } \\
\text { Degree }\end{array}$ & $\begin{array}{c}\text { Statistical } \\
\text { Significance }\end{array}$ \\
\hline $\begin{array}{c}\text { Information technology and its } \\
\text { impact on audit performance }\end{array}$ & 20 & 4.43 & 49. & 10.835 & 21 & 000. \\
\hline
\end{tabular}

Table 10 has indicated that there are statistical differences at $(=0.05)$ between arithmetic mean and standard deviation 3; T-value has been 10.835; statistical significance has been 0.000 . Accordingly, this hypothesis is rejected and the alternative hypothesis, stating that there is statistically significant relationship between the use of information technology and acceptance and the accuracy of audit performance in audit offices in the Hashemite Kingdom of Jordan, is accepted .

\section{Fifth Hypothesis Testing}

In order to validate this hypothesis, arithmetic means and standard deviations have been extracted; the relation between the impact of information technology and consultations in audit office has been measured. Table 11 outlines arithmetic means and standard deviations of consultations in audit offices .

Table 11. Arithmetic means and Standard Deviations of the Impact of Information Technology on consultations in audit offices

\begin{tabular}{lccc}
\hline \multicolumn{1}{c}{ Sentences } & $\begin{array}{c}\text { Arithmetic } \\
\text { mean }\end{array}$ & $\begin{array}{c}\text { Standard } \\
\text { Deviation }\end{array}$ & Answer Orientation \\
\hline $\begin{array}{l}\text { Consultations } \\
\begin{array}{l}\text { The office encourages the employees to consult on vocational matter and } \\
\text { information technology }\end{array}\end{array}$ & 4.43 & 0.53 & Very high impact \\
$\begin{array}{l}\text { Audit office adopts policies and procedures of consultations on specialized } \\
\text { information technology }\end{array}$ & 4.14 & 0.53 & High impact \\
\hline
\end{tabular}




\begin{tabular}{|c|c|c|c|}
\hline $\begin{array}{l}\text { The auditors of the office consult with (accredited ) persons in the } \\
\text { following matters: } \\
\text {-There is a suspicion of exiting errors or irregular matters in the light of } \\
\text { using information technology }\end{array}$ & 3.71 & 0.9 & High impact \\
\hline $\begin{array}{l}\text { Disputes related to information technology matters are not solved by task } \\
\text { employees }\end{array}$ & 3.71 & 0.9 & High impact \\
\hline $\begin{array}{l}\text { Technical rules related to information technology issued recently are } \\
\text { applied }\end{array}$ & 3.71 & 0.9 & High impact \\
\hline $\begin{array}{l}\text { The office saves a technical manual and issues technical instructions } \\
\text { related to information technology used and applied by the office }\end{array}$ & 4.43 & 0.9 & Very high impact \\
\hline $\begin{array}{l}\text { The office consults unofficially with other certain audit offices or persons } \\
\text { in order to address queries pertaining to information technology }\end{array}$ & 4.14 & 0.49 & High impact \\
\hline $\begin{array}{l}\text { The office depends on the opinions of internal consultants, particularly on } \\
\text { legal and legislative matters in the light of using information technology }\end{array}$ & 4.43 & 0.53 & Very high impact \\
\hline Electronic files of consultations are saved and they are used when needed & 4.43 & 0.9 & Very high impact \\
\hline Total & 4.43 & 0.96 & Very high impact \\
\hline
\end{tabular}

According to Table 11, the orientation of answers has indicated that information technology has a very high impact on consultations; total calculated arithmetic mean is 4.43; it is higher than the hypothetical mean which is 3. Thus, due to the necessity of using information technology, auditors need technicians to explain the subjects of information technology .

In addition, arithmetic mean of the paragraphs which form fifth hypothesis has been compared with standard mark 3- hypothesis acceptance standard- by using t-test as stated in table 12 .

Table 12. Arithmetic Means and Standard Deviations and T-test of Paragraphs which form fifth hypothesis

\begin{tabular}{ccccccc}
\hline & Number & $\begin{array}{c}\text { Arithmetic } \\
\text { Mean }\end{array}$ & $\begin{array}{c}\text { Standard } \\
\text { Deviation }\end{array}$ & T-Value & $\begin{array}{c}\text { Freedom } \\
\text { Degree }\end{array}$ & $\begin{array}{c}\text { Statistical } \\
\text { Significance }\end{array}$ \\
\hline $\begin{array}{l}\text { Information technology and } \\
\text { consultations in audit offices }\end{array}$ & 20 & 4.43 & 96. & 10.855 & 21 & 000. \\
\hline
\end{tabular}

Table 12 indicated that there are statistical differences at $(=0.05)$ between arithmetic mean and standard deviation 3; T-value has been 10.855; statistical significance has been 0.000 . Accordingly, this hypothesis is rejected and the alternative hypothesis, stating that there is statistically significant relationship between the use of information technology and the consultations in audit offices in the Hashemite Kingdom of Jordan, is accepted .

\section{Sixth Hypothesis Testing}

In order to validate this hypothesis, arithmetic means and standard deviations have been extracted; the relation between the impact of information technology and follow up procedures applied by audit office has been measured. Table 13 outlines arithmetic means and standard deviations of follow up procedures followed by audit offices .

Table 13. Arithmetic means and Standard Deviations of the Impact of Information Technology on follow up procedures applied by audit offices

\begin{tabular}{lccc}
\hline \multicolumn{1}{c}{ Sentences } & $\begin{array}{c}\text { Arithmetic } \\
\text { mean }\end{array}$ & $\begin{array}{c}\text { Standard } \\
\text { Deviation }\end{array}$ & Answer Orientation \\
\hline $\begin{array}{l}\text { f. supervisory control (inspection) } \\
\text { Audit office uses information technology in the procedures related to } \\
\text { supervisory control; these procedures ensure that office's policies and } \\
\text { procedures pertaining to audit quality work effectively. }\end{array}$ & 3.35 & 0.53 & Moderate impact \\
$\begin{array}{l}\text { Supervisory control procedures and programs include tasks selection } \\
\text { standards subjected to certain specifications related to information } \\
\text { technology }\end{array}$ & 3.37 & 0.53 & Moderate impact \\
$\begin{array}{l}\text { Electronic policies and procedures of supervisory control plus relevant } \\
\text { information are amended }\end{array}$ & 3.36 & 0.49 & Moderate impact \\
\hline Total & 3.37 & 0.18 & Moderate impact \\
\hline
\end{tabular}

Table 13 has indicated that total calculated arithmetic mean is 3.97; it is higher than the hypothetical mean which is 3 but it is not too high. It is noted that information technology has a moderate impact on inspection processes in audit offices .

In addition, arithmetic mean of the paragraphs which form sixth hypothesis has been compared with standard mark 3- hypothesis acceptance standard- by using t-test as stated in table 14 . 
Table 14. Arithmetic Means and Standard Deviations and T-test of Paragraphs which form sixth hypothesis

\begin{tabular}{ccccccc}
\hline & Number & $\begin{array}{c}\text { Arithmetic } \\
\text { Mean }\end{array}$ & $\begin{array}{c}\text { Standard } \\
\text { Deviation }\end{array}$ & T-Value & $\begin{array}{c}\text { Freedom } \\
\text { Degree }\end{array}$ & $\begin{array}{c}\text { Statistical } \\
\text { Significance }\end{array}$ \\
\hline $\begin{array}{c}\text { Information technology and follow } \\
\text { up procedures applied by audit } \\
\text { offices }\end{array}$ & 20 & 3.37 & 18. & 35.686 & 21 & 000. \\
& & & & & \\
\hline
\end{tabular}

Table 14 indicated that there are statistical differences at ( $=0.05)$ between arithmetic mean and standard deviation 3; T-value has been 35.686; statistical significance has been 0.000 . Accordingly, this hypothesis is rejected.

\section{Results and Recommendations}

\section{Results}

Following results are identified by statistical analysis :

- There is statistically significant relationship between the use of information technology and the compliance with vocational requirements applied by audit offices in the Hashemite Kingdom of Jordan .

- There is statistically significant relationship between the use of information technology and personal management applied by audit offices in the Hashemite Kingdom of Jordan .

- There is statistically significant relationship between the use of information technology and client acceptance and continuance applied in audit offices in the Hashemite Kingdom of Jordan .

- There is statistically significant relationship between the use of information technology and acceptance and the accuracy of audit performance in audit offices in the Hashemite Kingdom of Jordan .

- There is statistically significant relationship between the use of information technology and the consultations in audit offices in the Hashemite Kingdom of Jordan .

- There is statistically significant relationship between the use of information technology and following up and monitoring procedures applied by audit offices in the Hashemite Kingdom of Jordan .

\section{Recommendations}

Based on relevant references and statistical results, the study has recommended the following points :

- Authorities shall organize audit profession in Jordan; quality control department shall be exist in each audit office because it plays an important role in improving a level of audit performance .

- Using information technology shall be expanded since it contributes to organize audit offices, perform vocational requirements, and prepare audit programs, document audit processes and exchange information between audit offices and clients.

- Educational bodies shall be encouraged to modify audit course plans; information technology shall be applied in audit process; nature of audit task plus documents supporting the processes within information technology environment can be changed .

- Audit quality shall be activated in the light of international developments; researchers, scholars, and organizations locating in Jordan shall monitor vocational performance of auditors.

\section{References}

Abdel Fattah, S. (2000). Internal Control Procedures in Major Developments of Information Technology, Faculty of Commerce, Cairo University.

Abdul, W. N. A. (2002). accounting supervisor of Capital Market- Vocational Requirements and Problems of Practical Practice in the Light of International, Egyptian, and American Auditing Standards, Part 1, University House, Alexandria .

Adel Al-Shabrawi. (1995). Comprehensive Quality Management, Arab Media Company, Shuaa Al-Qahra.

Ahmad, N. (1992). Audit Theory and Practice, Shabab Al-Jamiah Library, Alexandria.

Ali Thneibat, (2003). Extent and Effectiveness of Using Information Technology In Audit Process in Jordan. Dirasat Journal, 30(2), 253-267.

Ali, N. (2001). Arab Culture and Information Age, Journal of The World of Knowledge, No. 276, Kuwait.

Amin, L. (2004). Encyclopaedia of International Standards For Audit, Cairo .

Helms. (2001). Traditional and Emerging Methods of the Electronic Assurance. The CPA Journal, August 2001. 
Hossam, E. K., \& Walid, S. (2003). Extent of Acceptance of Auditors For Using Information Technology In Audit, Field Study on the largest audit offices in Jordan. Journal of Administrative studies, 30(2), 279-289

International Federation of Accountants. (2002). Auditing and Ethical Conduct Issues, issued by the international Federation of Accountants, Translation of the Arab Society of Certified Accountants, Arab society of certified Public Accountants, Amman, Jordan, 2003.

International Federation of Accountants. (2010). International Standards For Auditing And Assurance, Publications of the Arab Society of Certified Accountants .

Karima, A., Saleh, A., \& Jamal, A. S. (2010). Impact of Using Information Technology On External Auditor Work, Field Study in Some Jordanian Audit Offices. Zarqa Journal For Research and Studies in Humanities, 10(2).

Khalid, A. A. (2000). Auditing - Practical side, Wael House For Publication, Amman.

Khalid, A. A. (2000). Auditing - Theoretical side, Wael House For Publication, Amman.

Law regulating legal Accounting Profession No.73, 2003

Legal Auditor Society System No. 24, 2001

Liang (2001). Electronically Auditing EDP Systems with the support of emerging information technologies. International Journal of Accounting Information Systems, 2(2), 130-147. https://doi.org/10.1016/S1467-0895(01)00014-8

Maher, A. (1999). Manual of Quality in Institutions and Companies, Al-Reda House Publishing, Damascus.

Mohammad, A. (2002). Abdel Wahab Naser Ali, External Audit: Basic Concepts and Application Mechanisms in Accordance with accredited International Standards, Aljamei Housing, Alexandria.

Mustafa, K. (1997). Audit: Concepts, Standards and Procedures, King Saud Unversity, Al-Riyadh.

Teoh, S. H., \& T. J, Wong, (1993). pereeived Auditor Quality \& the Earnigs Response Cofficient. The Accounting Review, 168(2).

The amended Company Law No. 22, 1997

William, T. (1989). Emerson Hankey, Auditing: Theory and Practice, Arabized by Ahmad Hamed Hajjaj, Al-Marikh Housing For Publishing, Al-Riyadh.

Willie, E, G., \& Ronald, A. D. (1999). An Explatory of Client Factors On Audit Time Budget Variancies" Auditing: A Journal of Paractice \& Therory, 180, I, Spring.

Zoe, V. P. (1988). An Anlysis of Auditor Litigation \& Service Quality. The Accounting Review, Jan.

\section{Copyrights}

Copyright for this article is retained by the author(s), with first publication rights granted to the journal.

This is an open-access article distributed under the terms and conditions of the Creative Commons Attribution license (http://creativecommons.org/licenses/by/4.0/). 